\title{
Relationship between Teacher Commitment to Students Learning Needs and Level of Students' Discipline in Public Secondary Schools in Naivasha Sub-County, Kenya.
}

\author{
Goodeve S.K Mwaniki ${ }^{1}$, Prof. J. Kanjogu Kiumi ${ }^{2}$, Dr. M. Ngunjiri ${ }^{3}$
}

Department of Curriculum and Education Management, Laikipia University, Kenya.

\begin{abstract}
The purpose of this study was to assess the relationship between teacher commitment to students learning needs and level of students' discipline in public secondary schools in Naivasha subcounty, Kenya. The study targeted a total of 197 respondents (constituting 28 head teachers and 169 teachers). A total of 195 respondents participated in the study (169 teachers and 26 principals) participated giving a response rate of $99 \%$. Purposive sampling technique was used to sample head teachers while Krejcie and Morgan's (1970) table for determining sample size for teachers. Questionnaires were used as instrument for data collection. SPSS was used to analyze the data where both descriptive and inferential statistics were used. The analyzed data were presented in terms of graphs and tables. The results showed that there was a significant positive relationship between teacher commitment to students learning needs and level of students' discipline $(\mathrm{r}=.271, \mathrm{p}=.000)$. Therefore, the null hypothesis that there was no significant relationship between teacher commitment to students learning needs and level of students' discipline was rejected at .05 level of confidence. The study therefore concluded that teacher commitment to students learning needs influences students' discipline in secondary schools in Naivasha sub-county. It was recommended that teachers should be more committed to meeting the students' learning needs. This can be achieved through holding discussions with parents on their children's academic performance and character development.
\end{abstract}

Key Words: Teacher commitment, students learning needs, students' discipline.

\section{INTRODUCTION}

Education has received unmatched attention as the best method of achieving a country's economic and social growth. It is the living bud of a nation's development (Muchemi, 2005). If a nation wishes to achieve any form of development, her people must be well socialized though a defined education system. It is through the education system that nations impart to their people the aspirations that will produce the citizens of their choice. The Kenyan government together with other stakeholders in education within and outside the country has invested heavily in education. Consequently, notable achievements have been realized in the country in regards to students' enrolment at all levels educations. For instance, at the secondary level of education, enrolment stood at $1,472,600$ in 2009. In 2014, enrolment had increased to $2,331,700$ representing a $58 \%$ increase rate within a period of five years. There has also been an upward trend in Gross Enrolment Ratio
(GER) and Net Enrolment Ratio (NER) in the Country at the secondary level of education. For instance, GER and NER at this level of education increased $16.4 \%$ and $14.3 \%$ respectively between 2009 and 2014 (MOEST, 2014).

The introduction of Free Primary Education (FPE) in 2003 resulted in increased enrolments in the primary schools and later in the subsequent secondary sub-sector. The period from 2003 therefore, has seen tremendous progress in the secondary sub-sector ranging from infrastructural and enrolment expansion to increased participation and transition rates (Republic of Kenya, 2009). For instance, there were a total of 5,019 public secondary schools in 2009. In 2014, there were a total of 7,686 secondary schools signifying an increase of 53\% (MOEST, 2014). This progress has 
been realized through the efforts of the government through initiatives like the Constituency Development Fund (CDF) and Local Authority Transfer Fund (LATF). Local communities and other Donor agencies have also helped in the expansion efforts of the educational institutions.

Education is widely valued across the world as a central factor in economic, political, and social development of any country (Republic of Kenya, 2012). The Constitution of Kenya 2010 articles 43.1f, 53.1b and 55a makes education a right of every Kenyan while the Kenya Vision 2030 underscores the importance of education in ensuring relevant human and social capital for sustainable development (Government of Kenya, 2010). In particular, the Constitution guarantees every child to free and compulsory basic education. It further provides for access to affordable tertiary education, training and skills development. According to the Bill of Rights 2010, basic education is a fundamental human right. Despite the importance of basic education, there are a number of challenges facing its implementation and the realization of its goals (Government of Kenya, 2010). Among the challenges to the realization of the goals of secondary education is indiscipline among students. This is because students' discipline does not only provide a sense of dissention among learners and hence commitment to school values, but also has an influence on teachers' job satisfaction, motivation and consequently commitment to students and students learning (Imber \& Neidt, 1990). This observation has the implication that in a school environment where students' level of discipline is low, learning achievement may undoubtedly be compromised. In Naivasha Sub-County, where the study was executed, a total of 7 schools experienced unrest between 2010 and 2015 which translated to $25 \%$ of the total number of secondary schools in the Sub-County (Naivasha Sub-County Education Office, 2015).

Several studies have been carried out to determine the causes of students' indiscipline in schools. A majority of the studies have tended to show that unfavorable home and school based factors are critical antecedents to students' indiscipline. For example, Lockheed (1991) observed that an orderly school environment is closely linked with schools where teachers gain and hold the attention of their students, maintain discipline, begin and end lessons on time and evaluate student performance regularly. Muchemi (2006) observed that a school environment that is safe, peaceful and free from student riots should be the effort of all the school management fraternity.

Eshiwani (2009) asserted that students' strikes are a symptom of inability of the schools to cultivate relevant morals among the youth and this situation threatens socio-economic development of the nation. According to Masese (2007), the result of student strikes include incidences such as rape, violence, loss of school property, loss of lives and loss of school time due to frequent closures. This in turn leads to poor examination performances and also wastage of potential human resources due to expulsion of students who may be linked to such disturbances. From this premise, it is clear that discipline is essential to smooth functioning of schools and the society at large.

Etizi (2008) defines discipline as a system of making the individual to make reasonable decision responsibly. Etizi further says that the goal of discipline is to make it possible for the individual or a team of individuals to succeed in the set goals. The term therefore denotes the kind of order involved in the efforts by trying to reach appropriate standards to follow appropriate rules for engaging in a valid activity. It requires freedom of choice and makes one to understand the consequences and is not imposed by authority figures but rather individual themselves (Charles, 1995). Therefore, with discipline in our learning institutions, we would have very rare cases of the student strikes. Griffin (1994) asserts that sound discipline is an essential ingredient in the creation of a happy and industrious school community, performing properly its function of training the citizens of tomorrow. Based on this background, this study therefore sought to assess whether there is any relationship between teacher commitment to students learning needs and discipline in schools.

\subsection{Statement of the Problem}

As it has been pointed out in the background part of the study, students' indiscipline in Kenyas' secondary schools is depicting a worrying trend. This is because; hardly a school term passes without incidents of indiscipline being reported in the mass media. This has the implication that if this behaviour trend goes unchecked, our secondary schools may not play their role expectations of producing responsible citizens. Evidence adduced from studies within and outside Kenya seems to suggest that unfavourable school and home environments are critical risk factors to students' misdemeanor. This study therefore assessed the relationship between teacher commitment to students learning needs and level of students' 
discipline in public secondary schools in Naivasha sub-county, Kenya.

\section{II: LITERATURE REVIEW}

This section presents the theory used in the study and the relevant literature on the relationship between teacher commitment to students learning needs and level of students' discipline and the theory used in the study.

\subsection{Theoretical Framework}

Choice Theory was developed by Glasser, a renowned American psychologist and psychiatrist (Glasser, 2009a). He theorized that behavior is a choice made by an individual, based on his or her feelings and needs, and is, therefore, not determined or controlled by external circumstances. In other words, the power lies within each person to determine how he or she will respond to the demands of the social and physical environment. Humans thus, should not be perceived as victims or slaves of circumstances, but as self-determining beings who take responsibility for the consequences of their choices.

According to Glasser (2009a) Choice Theory involves bringing learners to an awareness of their responsibility to make their own decision about their learning and behaviour in the classroom. This philosophy posits that students must have a choice, and that if they help choose their curriculum and decide on the rules in the classroom, they will then have ownership of their learning, have pride in their participation, will have higher self-esteem and will exhibit greater levels of self confidence and higher levels of cognition.

This approach to classroom management creates a safe space to learn, as mainly it is their space, their classroom, they own it. When this sense of ownership is established, they will come to class willingly and with enthusiasm because they want to be challenged. A key component of choice theory is that the basic need of personal competence is an inner drive that is self-initiating and is unrelated to the need for extrinsic rewards of praise or grades. Glasser (2009b) suggests that when dealing with discipline problems, teachers should have two goals: first, to stop the unwanted or challenging behaviour; second and more importantly, to teach students how to control their own behaviour. There is a distinct difference between "Teaching Student Responsible Behaviour" and the behaviour improvement programs offered by other organisations (Glasser, 2009b).
Only by understanding what drives an action or behaviour can educators be able to deal or manage the behaviour effectively. In choice theory, people or learners behave based on what they want, compared to what they see and know. Choice Theory clarifies reasons for human behaviour and also seems to explain how and why people behave as they do. This theory was used in this study to explain relationship between teachers attitude towards students discipline management and students' discipline. Choice theory was therefore used in this study to explain the influence of teacher commitment to students learning needs on discipline in schools.

\subsection{Teacher Commitment to Student Learning Needs}

Tumutoreine (2003) found that most un-rests in schools are due to poor- teachers-student relationships, which includes aspects of psychological defects. Fontana (1987) concurs with Tumutoreine when he noted that students are hurt when they realize that they are constantly ignored by those people who have an important role to play in their lives like parents and teachers.

Otieno (2012) argues that discipline in school is a system of guiding the students to make measurable decisions. At the classroom level it means the control of a class to achieve desirable behaviours. Thus good management of discipline saves substantial resources and time for stakeholders. Therefore, there is a general consensus that the class and subject teachers are bestowed with the responsibility of maintaining proper discipline in classes and the whole school in general and instill the appropriate moral values to the learners. The teacher(s) on duty oversees the students activities in the course of the time allocated while the dormitory masters/mistresses where applicable sees to it that there is order in their areas of jurisdiction.

Raichena (2006) observed that, good discipline should produce obedience and self-control. A student should be able to control himself/herself and do the right thing at the right time, place and in the right manner. Effective teachers should know that students need to enjoy firm and fair discipline. For their effectiveness to be felt, teachers should begin each day with a positive attitude, have a good class control, let the school activities be learners-centered and keep a record of major issues that arise in their areas of jurisdiction. To enhance the effectiveness of the teachers in their supervisory role, the head teacher and his/her deputy need to lead from the front. 
Donga (2007) asserts that adolescents are very sensitive and trying to demean them or force them into doing something they do not like could result in direct confrontation. Thus, teachers by using their position to humiliate and intimidate the learners cause indiscipline. The relationships teachers establish with their students have an influence on the development of self-concept which in turn affects discipline in class. Learners with poor selfconcept are more likely to display unacceptable behavior (Felix, 2011). Teachers who are often absent from school for no good reasons and who do not respond promptly to the bell for example, after break contribute to indiscipline (Donga, 2007).

Socially, teachers' discipline strategies have been suggested to be a potent force to promote students' sense of responsibility in the classroom and to produce more responsible citizens at a grand vision (Lewis, Romi, Qui, \& Katz, 2005). Effective teaching research also shows that a sufficient degree of classroom discipline is needed to create an atmosphere conducive to student learning as students' misbehavior distracts the process of learning and teaching and ruins the effectiveness of even the most carefully planned lessons (Barton, Coley \&Wenglinsky, 1998).

Teachers' behavior and management styles attach a special significance to this issue as the intervention techniques teachers choose to manage their classes are perceived to be the sign of their professional adequacy by students and an important motivator of learning (Muller, Katz, \& Dance, 1999). A nonthreatening learning environment develops a sense of belonging among students which makes them self-initiated and self-confident and thus increases their desire for learning (Freeman, Anderman, \& Jensen, 2007). Conversely, if teachers act coercively by adopting punitive discipline strategies, learning is negatively affected (Banfield, Richmond, \&McCroskey, 2006) and more psychological and somatic complaints are heard in the classroom (Sava, 2002). This issue complicates teacher role in the classroom and makes dealing with persistent behavior problems a formidable challenge that is one source of teacher job stress and burnout (Lewis, 1999).

Bank and Marlin (2001) conducted a study to examine parental and peer influence on adolescents. Subjects for the study consisted of 149 American adolescents enrolled in public high schools in a Midwestern state. The respondents constituted a quota-sample design that was approximately balanced for age, sex, social class, race, and community of residence. In comparison with the total population, the sample contained more blacks and disproportionately few whites who lived in rural areas. The researchers found that peer behaviours are more likely to affect the adolescent than parental behaviours, whereas parental norms are more likely to affect the adolescent than peer norms. Parents have had a longer time to influence adolescents and retain a responsibility to represent the standards of the adult world. Peers, in contrast, may be shunned if they attempt to impose standards on their adolescent friends but are likely to be omnipresent as behavioural models within schools (Bank \& Marlin, 2001). It is unfortunate that many adolescents do not have parents who are actively involved in their lives. Most parents do not provide appropriate supervision, and are unable to clearly communicate their values. This puts these adolescents in an even greater danger of giving in to negative peer pressure.

\section{III: METHODOLOGY}

This study was carried out in public secondary schools in Naivasha Sub-county of Nakuru County, Kenya. The Sub-County has 28 public secondary schools. Ex-post facto research design was used in the study. The target population for the study compromised head teachers and teachers of public secondary schools in Naivasha Sub-county. The population for the study was 314 subjects comprising 28 principals and 286 teachers. The study targeted a total of 197 respondents (constituting 28 head teachers and 169 teachers). A total of 195 respondents participated in the study (169 teachers and 26 principals) participated giving a response rate of $99 \%$. Principals were purposively selected for the study while teachers were sampled based on Krejcie and Morgan's (1970) table for determining sample size (n) from a given population $(\mathrm{N})$. A total of 169 teachers (n) were sampled from a total population of 286 teachers $(\mathrm{N})$ in the study area. Data was collected through a selfadministered questionnaire. Two sets of questionnaires, one for head teachers and the other for teachers were used to collect the data. The scoring in the questionnaire was done using a tick against the statement given in scale from definitely true, true, undecided and definitely not true. Primary data from the field were edited to minimize errors made by respondents. Coding was done to translate question responses into specific categories. The coded items were analyzed with the aid of a computer on SPSS. Normal scale data, specifically data on respondents and school characteristics were analyzed using frequency counts and percentages. Descriptive statistics such as frequencies and 
percentages were used while inferential statistics such as chi-square was used to test the relationships between the study variables.

\section{FINDINGS OF THE STUDY}

This section presents the findings of the study on the relationship between teacher commitment to students learning needs and level of students' discipline in public secondary schools in Naivasha sub-county, Kenya.

\subsection{Level of Students' Indiscipline As Reported by Principals and Teachers}

To establish the level of students' indiscipline, teachers and principals were asked to indicate the level of students' indiscipline in their schools. The findings are as presented Figure 1.

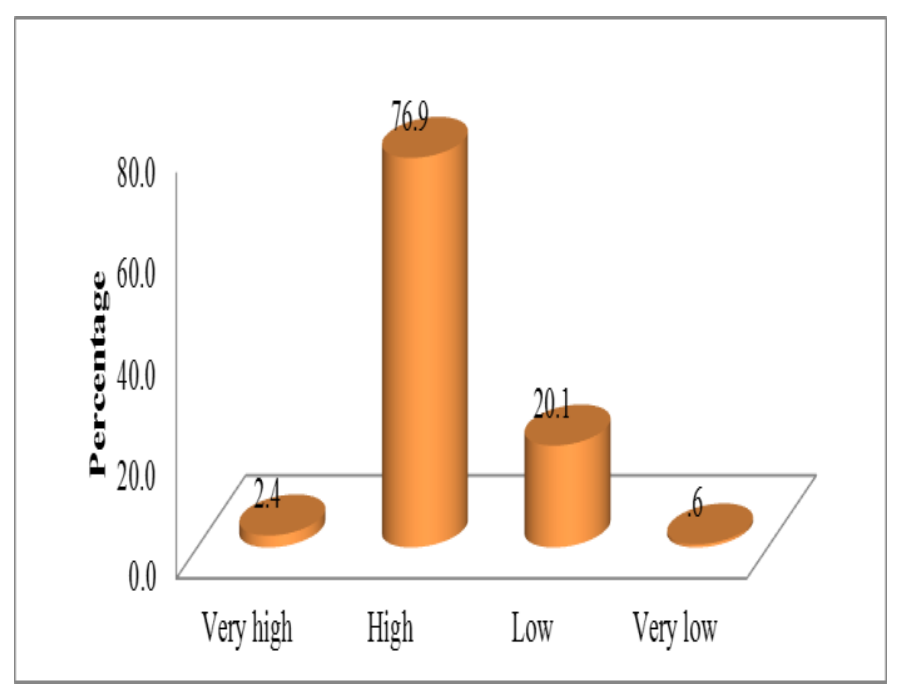

Source: Field Data (2017)

\section{Figure 1: Level of Students' Indiscipline in Secondary Schools in Naivasha Sub-County}

As is clearly shown in figure 1 , an overwhelming majority of teachers $(76.9 \%)$ reported that their students discipline was high. They were followed by $20.1 \%$ of teachers who indicated that students' level of discipline in their schools was low. Very few of the teacher respondents $(2.4 \%)$ reported that students' level of discipline in their schools was very high. Similarly, only $6 \%$ of the teacher respondents indicated that the level of students' discipline in their schools was very low.

\subsection{Teachers Commitment to Students Learning Needs}

Responses to the Likert scale items on teachers' commitment to students learning needs were analyzed. This was accomplished by adding respondents' scores for each item and dividing by the number of respondents $(\mathrm{n}=$ number of principals). The mean scores are presented in Table 1.

\section{Table 1}

Teachers Commitment to Students Learning Needs

\section{Statement}

Failure by some teachers to go an

extra mile to enhance students

Mean

success in schools

Failure by some teachers to cover

syllabus on time

Tendency by some teachers to delay

in releasing results of marked work to

students

Failure by some teachers to

effectively participate during school

based parent-teacher conferences on

students academic life

Tendency by some teachers to be less

interested in meetings arranged to

discuss students academic matters

Late attendance of lessons by some

teachers

Failure by some teachers to respond

to students concerns on academic

matters

Lack of concern by some teachers towards students who consistently register low academic performance Tendency by some teachers to accord look warm commitment to academic benchmarking activities

Failure by some teachers to search for extra teaching/learning materials, thereby relying only on resources

availed by the school

\section{Source: Field Data (2017)}

A look at the data shown in table 1 demonstrates that the highest rated teachers commitment to students learning needs was failure by some teachers to go an extra mile to enhance students success in schools (mean 4.15), failure by some teachers to cover syllabus on time (mean 4.04) and tendency by some teachers to delay in releasing results of marked work to students (mean 3.58). The least rated teachers commitment to students learning needs was lack of concern by some teachers towards students who consistently register low academic performance (mean 2.35), tendency by some teachers to accord look warm commitment to academic benchmarking activities (mean 2.35) and failure by some teachers to search for extra 
teaching/learning materials, thereby relying only on resources availed by the school (mean 2.12).

\subsection{Hypothesis test on Teachers Commitment to Students Learning Needs and Students' Discipline}

The objective of the study was to determine whether there is any statistically significant relationship between teacher commitment to students learning needs and students' discipline in public secondary schools in Naivasha sub-county, Kenya. In order to achieve this objective, the following null hypothesis was formulated and stated as follows:

H01: There is no statistically significant relationship between teacher commitment to students learning needs and students' discipline in public secondary schools in Naivasha subcounty, Kenya

The findings, therefore, presumed that teacher commitment to students learning needs is not linked to students' discipline. To ascertain the truth of this assumption, the hypothesis was tested using data generated from likert scale findings as presented in Table 2 and Pearson correlation coefficient in Table 3.

Table 2: Teacher Commitment to Students Learning Needs and Students' Discipline

\begin{tabular}{|c|c|c|}
\hline Principals & $\mathbf{Y}$ & $\mathbf{X}$ \\
\hline 1. & 30 & 56 \\
\hline 2. & 29 & 56 \\
\hline 3. & 42 & 56 \\
\hline 4. & 42 & 56 \\
\hline 5. & 42 & 57 \\
\hline 6. & 30 & 42 \\
\hline 7. & 28 & 30 \\
\hline 8. & 28 & 30 \\
\hline 9. & 28 & 30 \\
\hline 10. & 28 & 30 \\
\hline 11. & 28 & 30 \\
\hline 12. & 33 & 34 \\
\hline 13. & 28 & 30 \\
\hline 14. & 28 & 30 \\
\hline 15. & 28 & 30 \\
\hline 16. & 37 & 31 \\
\hline 17. & 29 & 30 \\
\hline 18. & 28 & 30 \\
\hline 19. & 42 & 30 \\
\hline 20. & 28 & 30 \\
\hline 21. & 28 & 27 \\
\hline 22. & 42 & 30 \\
\hline 23. & 28 & 52 \\
\hline 24. & 28 & 51 \\
\hline 25. & 28 & 51 \\
\hline 26. & 28 & 51 \\
\hline
\end{tabular}

Source: Field Data (2017)

$\mathrm{X}=$ Students discipline

$\mathrm{Y}=$ Teacher commitment to Students learning needs

Table 3: Correlation Between Teacher Commitment to Students Learning Needs and Students Discipline

\begin{tabular}{lll}
\hline & $\mathrm{R}$ & $\mathrm{P}$ \\
\hline Pearson Coefficient & .271 & .000 \\
No of Valid Cases & 26 & \\
\hline
\end{tabular}

Source: Field Data (2017)

Table 3 shows that there was a significant positive relationship between teacher commitment to students learning needs and students discipline $(\mathrm{r}=$ $.271, \mathrm{p}=.000$ ). Therefore, the null hypothesis that there was no significant relationship between teacher commitment to students learning needs and students discipline was rejected at .05 level of confidence. It can therefore be concluded that teacher commitment to students learning needs influences students' discipline in schools.

The findings in this study are in line with that of Freeman, Anderman and Jensen (2007) who found that, a non-threatening learning environment develops a sense of belonging among students, makes them self-initiated and self-confident and thus increases their desire for learning. Conversely, if teachers act coercively by adopting punitive discipline strategies, learning is negatively affected and more psychological and somatic complaints are heard in the classroom (Banfield, Richmond, \& McCroskey, 2006).

Otieno (2012) argues that discipline in school is a system of guiding the students to make measurable decisions. At the classroom level it means the control of a class to achieve desirable behaviours. Thus, good management of discipline saves substantial resources and time for stakeholders. Therefore, there is a general consensus that the class and subject teachers are bestowed with the responsibility of maintaining proper discipline in classes and the whole school in general and instill the appropriate moral values to the learners. The teacher(s) on duty oversees the students activities in the course of the time allocated while the dormitory masters/mistresses where applicable sees to it that there is order in their areas of jurisdiction.

\section{V.SUMMARY OF THE FINDINGS OF THE STUDY}

Teacher commitment to students learning needs had a significant relationship with student indiscipline in schools $(\mathrm{r}=.271, \mathrm{p}=.000)$. Hence the null 
hypothesis was therefore rejected at .05 level of significance.

\section{CONCLUSIONS}

From the findings of the study, it was clear that teacher commitment to students learning needs had statistically significant influence on students' indiscipline. The three teacher commitment dimensions that appeared to have a negative effect on discipline were; failure by teachers to put extra effort to enhance students' success in schools, failure to cover syllabus on time, and delay in releasing marked assignments to students. It can therefore be concluded that these teacher based factors had appreciable negative effect of students' discipline in Secondary schools in Naivasha SubCounty.

\section{RECOMMENDATIONS}

The study recommends that teachers should be more committed to meeting the students' learning needs. This can be achieved through holding discussions with parents on their children's academic performance and character development.

\section{REFERENCES}

[1] Banfield, S. R., Richmond, V. P., \&McCroskey, J. C. (2006). The effect of teacher misbehaviors on teacher credibility and affect for the teacher.Journal ofCommunication Education.Vol 55, 63-72.

[2] Bank, B.J., \& Marlin, M. M. (2001).Parental and Peer influence on adolescents.Social Forces.Vol 58, 1057-1079

[3] Barton, P. E., Coley, R. J., \&Wenglinsky, H. (1998).Order in the classroom: Violence, discipline and student achievement. Princeton, NJ: Policy Information Center, Educational Testing Service.

[4] Charles, L. (1995). Drug behaviour and modern society ( $2^{\text {nd }}$ Edition).Boston: Edward and Arnold.

[5] Donga, M.M., (2007). The causes and consequences of indiscipline in public and independent secondary schools: A comparison Afrikaans University, New York: Oxford University press.

[6] Eshiwani, G (2009). University Expansion in Eastern Africa: Challenges and Options in Higher Education. Inter-University Council for East Africa (IUCEA).Newsletter Vol. 39 pp 1722.
[7] Etizi, M. (2008).Effective student discipline: Methods for teachers. Nairobi: Shrend Publishers.

[8] Felix, T. (2011)."Leaving to be violent, the role of school in developing adolescent gendered behaviours."South African Journal of Education :EASA.33(3):385-398.

[9] Fontana. D. (1987).Classroom control.Understanding and guiding classroom behaviour. New York -USA AB printers limited.

[10]Freeman, T., Anderman, L, \& Jensen, J. (2007).Sense of belonging in college freshman at the classroom and campus levels.Journal of Experimental Education, Vol. 75, 203-220.

[11]Glasser, W. (2009a).Introduction to choice theory: Teaching students responsible behaviour. San Pedro Quality Education Programs, Inc.

[12]Glasser, W. (2009b).Classroom management: Dealing with discipline problems. San Pedro. Quality Education Programs, Inc.

[13]Government of Kenya (2010).Vision 2030.Ministry of Education, Nairobi, Government printer.

[14]Griffin, G. (1994). School mastery: Straight talk about boarding schools management in Kenya. Nairobi: Lectern Publication Ltd.

[15]Imber, M \& W. A. Neidt. (1990) Teacher participation in school decision making.Newsbury Park: Sage Publication Inc.

[16] Krejcie, R.\& Morgan, D. (1970). Determining sample sizes of research activities. Education and Psychological Measurement, Vol. 30, 607610.

[17]Lewis, R. (1999). Teachers coping with the stress of classroom discipline. Social Psychology of Education, Vol.3, 1-17.

[18]Lewis, R., Romi, S., Qui., X., \& Katz, Y. (2005). A comparison of teachers' classroom discipline in Australia, China and Israel.Teaching and Teacher Education, Vol 21,729-741.

[19]Lockheed, M.(1991) .Improving education. Education Review.Vol 16 (3)303-311.

[20]Masese, A (2007).A Study of the causes of Drug Abuse Among students in selected Secondary schools in Kisumu Municipality,Kenya.( Unpublished master's thesis) Kenya, University of Nairobi.

[21]MOEST (2014).Basic Education Statistical Booklet. Nairobi, UNICEF.

[22]Muchemi, N. C. (2006). Management of Student Riots in public secondary schools in Meru South 
District, (Unpublished Med Thesis) Nairobi, Kenyatta University.

[23] Muchemi, W. (2005).Education the living bud of a nation's development. Daily Nation,p23. June 22.

[24]Muller, C., Katz, S. R., \& Dance, L. J. (1999).Investing in teaching and learningdynamics of the teacher-student relationship from each actor's perspective.Urban Education, Vol. 34, 292-337.

[25]Naivasha Sub-County Edication office (2015).

[26]Otieno, J. (2012). Promotion- Career progression and professional development, a guide to T.S.C interviews, Nairobi, Rinny Educational and Technical Services.

[27]Raichena, H. (2006). "Presentation paper to deputy principals' induction course in education management," (Unpublished paper) Nairobi, Kilimambogo Teachers Training College, Kenya.

[28]Republic of Kenya (2009).Ministry of Education: Education Management Information System, Facilitator Guide for EMIS Training. Nairobi: Ministry of Education.

[29]Republic of Kenya.(2012). Sessional Paper No. 14 of 2012 on realigning Education and Training to the Constitution of Kenya 2010 and Vision 2030 and beyond.Ministry of Education and Ministry of Higher Education, Science and Technology. Nairobi: Government Printers.

[30]Tumutoreine, N. (2003). Causes of unrest in government aided secondary schools in Ntungamo district. (Unpublished MED dissertation) Kampala, Makerere University. 